\title{
Maturation of Secretory Function in Rat Pancreas
}

\author{
STEVEN L. WERLIN ${ }^{(17)}$ AND JOHN STEFANIAK \\ Department of Pediatrics (Division of Gastroenterology), The Medical College of Wisconsin and Milwaukee Children's \\ Hospital, Milwaukee, Wisconsin
}

\begin{abstract}
Summary
In contrast to morphologic maturity, the newborn rat pancreas is unresponsive to carbachol. At $\mathbf{2 4} \mathrm{h}$, carbachol-stimulated secretion of exportable proteins markedly increases. Responsiveness to the calcium ionophore, A23187, is present at term. At age $24 \mathrm{~h}$, pancreas from fasted newborn rats is also unresponsive to carbachol. When cholecystokinin octapeptide or hydrocortisone was administered to fasted newborn rats secretory function developed normally. Thus, responsiveness of newborn rat pancreas to secretagogues matures rapidly and can be induced by hormones.
\end{abstract}

\section{Speculation}

When either cholecystokinin octapeptide or hydrocortisone is administered to fasted newborn rats, normal maturation of in vitro secretory function occurs. The actions of these exogenous agents may mimic endogenous release stimulated by first feeding.

The term fetal rat pancreas is morphologically mature and $\alpha$ amylase (EC 3.2.1.1), chymotrypsinogen (EC 3.4.4.5), trypsinogen (EC 3.4.4.4) and lipase (EC 3.1.1.3) concentrations are at adult levels $(9,10)$. In contrast to morphologic development, the term fetal rat pancreas is insensitive to secretagogues, $(3,13)$ although sensitive to the calcium ionophore, $\operatorname{A23187}(3,13)$. The exact time that functional maturity appears is disputed. We (13) found sensitivity to cholinergic stimulation at $24 \mathrm{~h}$ of age, Doyle and Jamieson (3) at day 21 of gestation and LaRose and Morriset (7) at 3 days of age. Because of this controversy, we felt that it would be of interest to establish the developmental pattern of the rat pancreatic acinar cell sensitivity to cholinergic stimulation, as well as the effects of feeding and fasting on the developmental process. Since we have also shown that cholecystokinin octapeptide (CCK$\mathrm{OP}$ ) and hydrocortisone (HC) induce premature maturation of pancreatic secretory function in the offspring of treated rats, we also evaluated the effects of these agents on the development of the secretory process. $(14,15)$.

\section{MATERIALS AND METHODS}

All experiments were performed on Sprague-Dawley rats obtained from King Laboratories, Oregon, WI. Term fetal rats (22 day gestation) were obtained from timed pregnancies. Infant rats were not disturbed and were allowed to nurse until the time of the experiment. In order to study fasted rats, newborn rats were separated from the dams before suckling, and kept at $34^{\circ} \mathrm{C}$. Subcutaneous injections of $500 \mu \mathrm{l}$ of $5 \%$ dextrose were given shortly after birth and at $12 \mathrm{~h}$ of age. To study the effects of CCKOP and $\mathrm{HC}$, either CCK-OP $(5 \mu \mathrm{g} / \mathrm{kg})$ or $\mathrm{HC}(10 \mathrm{mg} / \mathrm{kg})$ (in 0.1 $\mathrm{ml}$ saline) was administered with the first injection of $5 \%$ dextrose and the rats were then fasted.

Reagents. Carbamylcholine chloride (carbachol) was obtained from Sigma Chemical Co., St. Louis, MO. Trypsin and soybean trypsin inhibitor were from Worthington Biochemical Corp., Freehold, NJ. Amino acids (minimal essential medium mixture (MEM), 50 times concentrated) were purchased from Grand
Island Biochemical Co., Grand island, NY and hydrocortisone was from Upjohn Co, Kalamazoo, MI. Phadebas amylase test tablets were from Pharmacia Diagnostics, Piscataway, N.J. A23187 was a gift from Eli Lilly and Co., Indianapolis, IN, courtesy of Dr. R. Hamill. Cholecystokinin octapeptide was a gift of Squibb Pharmaceutical Co., Princeton, N.J., courtesy of Mr. S. J. Lucania. All other regents were of analytical grade.

Preparation of tissue. Tissue was prepared as previously reported except that whole pancreas is now used (13). Rats were decapitated; pancreas was rapidly excised and immersed in Krebs-Ringer bicarbonate buffer (KRB) containing $\mathrm{NaCl}, 123 \mathrm{mM}$; KCl, 4.9 $\mathrm{mM} ; \mathrm{MgCl}_{2}, 1.2 \mathrm{mM} ; \mathrm{CaCl}_{2}, 2.52 \mathrm{mM} ; \mathrm{NaHCO}_{3}, 21.0 \mathrm{mM}$; $\mathrm{KH}_{2} \mathrm{PO}_{4}, 1.2 \mathrm{mM}$; glucose $13.9 \mathrm{mM}$; and MEM amino acids (50X) $2.6 \mathrm{ml} /$ liter, pH 7.4 equilibrated with $95 \% \mathrm{O}_{2}-5 \% \mathrm{CO}_{2}$ at $37^{\circ} \mathrm{C}$. Soybean trypsin inhibitor ( $200 \mathrm{mg} / \mathrm{liter}$ ) was added to all incubations when chymotrypsinogen secretion was not measured. When fetuses were studied, the dam was sacrificed by cervical dislocation. The fetuses were rapidly delivered by cesarean section and anesthetized by chilling on ice. The pancreas was then removed, placed in constantly gassed $\mathrm{KRB}$ at $37^{\circ} \mathrm{C}$ and trimmed of connective tissue and blood vessels. Whole pancreas was preincubated for $15 \mathrm{~min}$ in $20 \mathrm{ml} \mathrm{KRB}$ under $95 \% \mathrm{O}_{2}-5 \% \mathrm{CO}_{2}$. After two washes with $20 \mathrm{ml}$ fresh KRB, approximately $20-40 \mathrm{mg}$ tissue was placed in $3 \mathrm{ml}$ of $\mathrm{KRB}$ in a $25 \mathrm{ml}$ Erlenmeyer flask containing the compound to be tested. Tissue was gassed with $95 \% \mathrm{O}_{2}-5 \%$ $\mathrm{CO}_{2}$. Incubations were performed at $37^{\circ} \mathrm{C}$ in a Dubnoff shaker bath.

Secretory studies. After incubation of the pancreatic tissue for $60 \mathrm{~min}$, aliquots of media were removed and stored frozen $\left(-20^{\circ} \mathrm{C}\right)$ for subsequent enzyme determination. The tissue was washed in $3 \mathrm{ml}$ fresh $\mathrm{KRB}$ and homogenized in $1 \mathrm{ml} 0.02 \mathrm{M}$ sodium phosphate buffer $\left(\mathrm{pH} \mathrm{6.9)}\right.$, and frozen $\left(-20^{\circ} \mathrm{C}\right)$ for amylase and chymotrypsinogen determination. Amylase was determined by the method of Ceska et al. (2) using the Phadebas reagent tablets. Chymotrypsinogen was determined by the method of Hummel (6) after activation with trypsin $(15 \mu \mathrm{g} / \mathrm{ml})$ for $2 \mathrm{~h}$ at $4^{\circ} \mathrm{C}$. Enzyme activity was expressed as the $\%$ of total tissue activity that appeared in the incubation medium.

Results of the time course experiments were analyzed by two way analysis of variance taking into account the effects of different litters. Results of the hormone studies were tested by one way analysis of variance.

\section{RESULTS}

The results of the timed secretory studies are illustrated in Figure 1. Carbachol was always used at $10^{-6} \mathrm{M}$ as we have previously shown this to be the optimal concentration for studies in the perinatal period (13). Only at $24 \mathrm{~h}$ was secretion of amylase and chymotrypsinogen significantly greater $(P<0.001)$ from carbachol stimulated pancreas than from control (Fig. 1, Table 1). By contrast calcium ionophore, A23187, significantly increased secretion of amylase and chymotrypsinogen at term (Table 1).

It is not noteworthy that amylase was preferentially secreted when pancreas was stimulated with A23187 but chymotrypsinogen was preferentially secreted in response to carbachol stimulation. 
We next studied the effects of enteral feeding on secretory function of newborn pancreas. After fasting, at $24 \mathrm{~h}$ of age, carbachol-stimulated amylase release was not different from that of the newborn fed rats at ages less that $24 \mathrm{~h}$ (Fig. 2).

Newborn rats were separated from their mothers at birth, treated with CCK-OP or HC and then fasted. At $24 \mathrm{~h}$ of age, the pancreas from these treated rats responded to carbachol stimulation with amylase secretion similar to the fed rats (Fig. 2).

\section{DISCUSSION}

The data presented here confirm our previous findings that in vitro, the cholinergic secretory mechanism of the term fetal rat

\section{SECRETORY RESPONSE OF RAT PANCREAS 60 MINUTE INCUBATION}

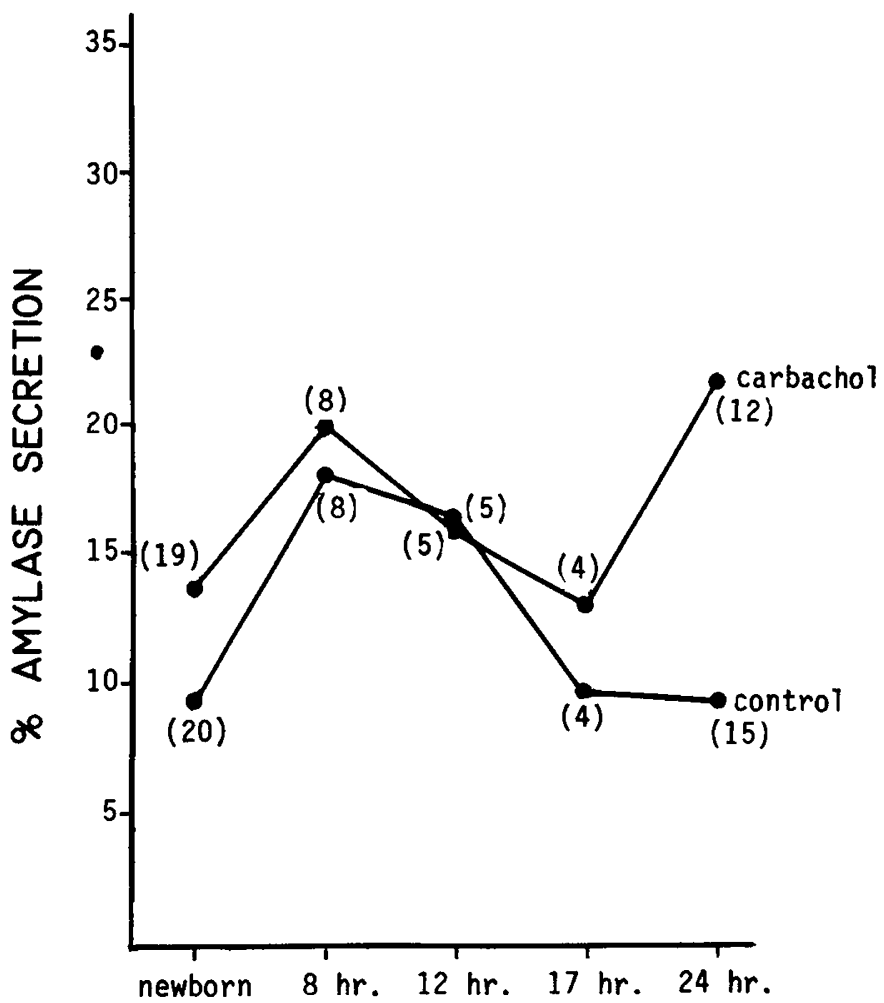

Fig. 1. Secretory response of rat pancreas. Pancreas from rats of varying ages were incubated for $1 \mathrm{~h}$ in $\mathrm{Krebs}$ Ringer Bicarbonate at $37^{\circ} \mathrm{C}$ with or without carbachol $\left(10^{-6} \mathrm{M}\right)$. Amylase was measured in medium and tissue homogenate and expressed as percent secretion. Results shown are mean of at least four separate experiments. The number of experiments is in parenthesis. pancreas is immature, and that functional maturity for amylase secretion is reached by $24 \mathrm{~h}$ of age (13). We have now shown that in vitro, the cholinergic secretory mechanism for amylase remains immature at age $17 \mathrm{~h}$; however, at $24 \mathrm{~h}$ of age the rat pancreas responds to carbachol stimulation with significantly increased secretion not only of amylase but also of chymotrypsinogen. This suggests that maturation of the secretory process for both enzymes is parallel and thus probably parallel for all exportable pancreatic proteins, although the response to different secretagogues is not parallel.

These findings differ from those of Doyle and Jamieson (3) who found secretion from the term fetal and newborn rat pancreas and from those of Larose and Morriset (7) who found no secretion until 3 days of age. These investigators used carbachol (3) or bethanechol (7) at a concentration of $10^{-5} \mathrm{M}$, the concentration most effective in mature pancreas. If, as postulated by Dumont and colleagues (4), the receptor population is low at birth, then cholinergic secretagogues at $10^{-5} \mathrm{M}$ might interact with lower affinity inhibitory, receptors, thus depressing secretion. On the other hand Doyle and Jamieson state that in pancreatic lobules $10^{-5} \mathrm{M}$ was the most effective dose, although dose response curves were not reported.

There is clearly a parallel increase in both basal and stimulated amylase secretion at $8 \mathrm{~h}$ of age $(P<0.05)$, which progressively falls at 12 and $17 \mathrm{~h}$. We have no explanation for these changes.

The lack of parallel secretory response to carbachol and A23187 is not surprising as we have previously found nonparallel changes in secretory response in the offspring of pregnant rats treated with CCK-OP, HC and bethanechol (14). This may be secondary to

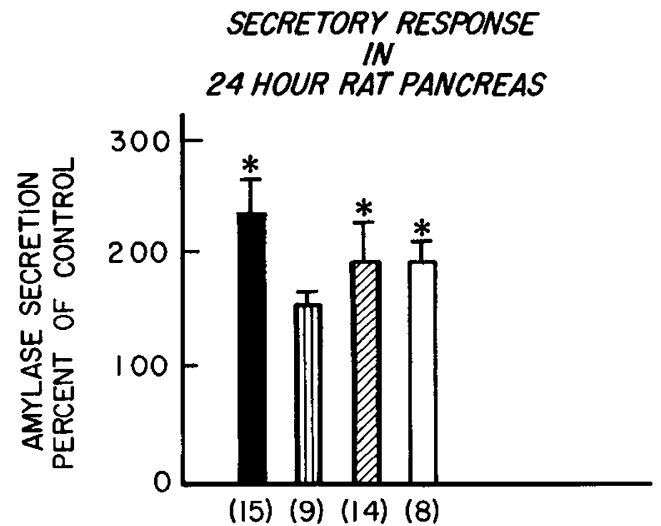

Fig. 2. Secretory response of 24-h-old rat pancreas. Pancreas from 24h-old rats was incubated for $60 \mathrm{~min}$ in Krebs Ringer Bicarbonate at $37^{\circ} \mathrm{C}$ with or without carbachol $\left(10^{-6} \mathrm{M}\right)$. Amylase was measured in medium and tissue homogenate. Values expressed are percent of control amylase secretion with carbachol stimulation \pm S.E. Number of experiments is in parenthesis. [回] Fed; [D] enterally fasted; [国] enterally fasted plus CCK$\mathrm{OP} ;[$ ] enterally fasted plus hydrocortisone; * significantly greater than corresponding control. $(P<0.05)$.

Table 1. Development of secretory response in rat pancreas ${ }^{1}$

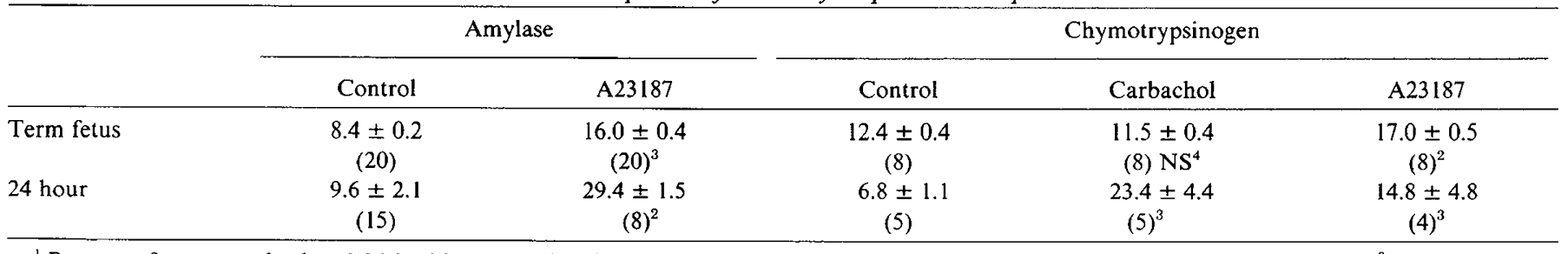

${ }^{1}$ Pancreas from term fetal and $24 \mathrm{~h}$ old rats was incubated in Krebs Ringer bicarbonate at $37^{\circ} \mathrm{C}$ for 60 min with carbachol (10-6 $\left.\mathrm{M}\right)$ or $\mathrm{A} 23187(3$ $\mu \mathrm{g} / \mathrm{ml}$ ). Enzyme was measured in medium and tissue homogenates. Values are $\% \pm$ S.E. of total enzyme secreted. Number of incubations for each agent is in parenthesis.

${ }^{2}$ Significantly greater than corresponding control $(P<0.05)$.

${ }^{3}$ Significantly greater than corresponding control $(P<0.001)$.

${ }^{4} \mathrm{NS}$, not significantly greater than corresponding control. 
immaturity of the secretory process or to segregation of pools of exportable proteins.

In the present study, we found a lower secretion of amylase at $24 \mathrm{~h}$ of age for both control and carbachol-stimulated incubations than in our previous study (13). We have made two changes in technique since that study. First, mineral concentrations in the incubation medium have been altered slightly. Second, we now use whole pancreas instead of tissue slices. Whole newborn pancreas is actually thinner than the slices used from 8-day-old pancreas in our previous study (13). The second change has considerably reduced experiment to experiment variability. This is probably because tissue damage is decreased, which is also the likely explanation for the decrease in both basal and stimulated secretion from the 24-h-old pancreas. Secretion from the term fetal pancreas was similar in both studies.

The insensitivity to cholinergic agents is undoubtedly related to a step proximal to $\mathrm{Ca}^{++}$mobilization and cyclic GMP generation. We have previously shown that the immature pancreas responds to both A23187 and 8-Bromo-GMP with increased amylase release (13). Now we demonstrate that A23187 will also stimulate the secretion of chymotrypsinogen. Additionally, although the mature pancreas generates cyclic GMP in response to carbachol (5); the fetal pancreas does not (13).

The starvation experiment establishes that enteral feeding, gastric distension, or suckling is the key event in physiologic regulation of pancreatic exocrine functional maturity. The explanation for the functional immaturity is still not known. It would seem likely that the hormone receptors are not present, are inactive, or are inhibited.

On a teleologic basis, it seems reasonable that the secretory process is immature in the prenatal rat as the fetus is nourished via the placenta and pancreatic secretion is not required by the fetus for digestion. Cholecystokinin is known to be a trophic agent for the mature pancreas (1). Treatment of newborn enterally starved rats with CCK-OP produces functional maturation of the pancreas at $24 \mathrm{~h}$ of age, (Fig. 2), similar to feeding. This suggests that the critical event stimulating maturation is related to postnatal enteral feeding and the release of cholecystokinin, which then acts, in a presently unknown way, on the pancreatic acinar cell. Supporting this view is the fact that CCK-OP, when injected into pregnant rats, will alter enzyme and DNA content in the fetal pancreas and induce premature maturation of secretory function $(14,15)$.

Similarly HC, which induced maturation of secretory function in enterally starved rats, also induced premature maturation of fetal pancreas when injected into pregnant rats $(14,15)$. Whether this is a physiologic or pharmacologic effect is not known, however
$\mathrm{HC}$ is important for maturation of pancreas in vivo $(11,12)$ and in organ culture (8) suggesting that it may play a role in the physiologic development of pancreatic secretory function in the immature rat.

\section{REFERENCES AND NOTES}

1. Barrowman, J. A., and Mayston, P. D.: The trophic influence of cholecystokinin on the rat pancreas. J. Physiol., 238: 73, (1974).

2. Ceska, M., Brown, B., and Birath, K.: Ranges of alpha-amylase activities in human serum and urine and correlations with some other alpha-amylase methods. Clin. Chim. Acta., 26: 445, (1969).

3. Doyle, C. M., and Jamieson, J. D.: Development of secretagogue response in rat pancreatic acinar cells. Dev. Biol., 65: 11, (1978).

4. Dumont, Y., Poircer, G. G., LaRose, L., and Morisset, J.: Parallel maturation of the pancreatic secretory response to cholinergic and the muscarinic receptor population (abstract). Newsletter National Pancreatic Cancer Project, Volume 5. November 1980.

5. Haymovits, A., and Scheele, G. A.: Cellular cyclic nucleotides and enzyme secretion in the pancreatic acinar cell. Proc. Nat. Acad. Sci., 73: 156, (1976).

6. Hummel, B. C. W.: A modified spectrophotometric determination of chymotrypsin, trypsin and thrombin. Can. J. Biochem. Physiol., 37: 1393, (1959).

7. LaRose, L., and Morriset, J.: Acinar cell responsiveness to urecholine in the rat pancreas during fetal and postnatal growth. Gastroenterology, 73: 530 (1977).

8. McEvoy, R. C., Hegre, O. D., and Lazarow, A.: Fetal and neonatal rat pancreas in organ culture. Age-related effects of corticosterone on the acinar cell component. Am. J. Anat., 146: 133, (1976).

9. Pictet, R. K., Clark, W. R., Williams, R. H., and Rutter, W. J.: An ultrastructura analysis of the developing embryonic pancreas. Dev. Biol., 29: 436, (1972)

10. Sanders, T. G., and Rutter W. J.: The developmental regulation of amylolytic and proteolytic enzymes in the embryonic rat pancreas. J. Biol. Chem., 249: 3500, (1974).

11. Sasaki, R., Mura, M., Takeuchi, T.,Furihata, C., Matsushima, $\Upsilon$., and Sagimura T.: Premature induction of amylase in pancreas and parotid gland of growing rats by dexamethasone. Biochem. Biophys. Acta., 428: 619, (1976).

12. Takuma, T., Nakanishi, M., Takagi, Y., Tanemura, T., and Kumegawa, M. Y. Precocious differentiation of mouse parotid glands and pancreas induced by hormones. Biochem. Biophys. Acta., 538: 376, (1978).

13. Werlin, S. L., and Grand, R. J.: Development of secretory mechanism in rat pancreas. Am. J. Physiol., 236: E446, (1979).

14. Werlin, S. L.: Effects of hydrocortisone, CCK-OP and bethanechol on immature rat pancreas. (abstract). Newsletter National Cancer Project, Volume V, November, 1980.

15. Werlin, S. L.: Effects of hydrocortisone and cholecystokinin-octapeptide on maturity of rat pancreas (abstract). Pediatr. Res., 15: 490, (1981).

16. This paper was presented in part at the meeting of the Society for Pediatric Research, April 29, 1981, in San Francisco and published in abstract form. This study was supported by U.S.P.H.S. Grant No. F.D 12447 and by grants from Milwaukee Children's Hospital and the Medical College of Wisconsin. The authors are indebted to Raymond Hoffman. Ph.D. ior assistance with the statistical analysis. The authors wish to thank Mrs. Le-Vern Boyd for typing this manuscript.

17. Requests for reprints should be addressed to: Dr. Steven L. Werlin, Department of Pediatrics, Milwaukee Children's Hospital, 1700 West Wisconsin Avenue P.O. Box 1997, Milwaukee, WI 53201

18. Received for publication April 27, 1981.

19. Accepted for publication July 14, 1981 . 